https://www.amerabra.org; https://fspu.uitm.edu.my/cebs; https://www.emasemasresources.com/ $5^{\text {th }}$ ABRA International Conference on Quality of Life Holiday Villa Langkawi, Langkawi Island, Malaysia, 15-16 Dec 2021

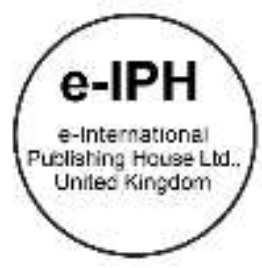

\title{
Architecture and Contextualism in Mosque Design as a Multi-faith and Community Friendly Place
}

\author{
Intan Liana Samsudin 1,2, Zurinda Mat Rabu ${ }^{2}$, Ida Marlina Mazlan 2 ${ }^{2}$, Yakubu Aminu Dodo ${ }^{3}$ \\ ${ }^{1}$ Department of Architecture, Faculty of Built Environment \& Surveying, \\ Universiti Teknologi Malaysia, Johor, Malaysia \\ 2 School of Architecture \& Built Environment, Faculty of Engineering, Technology and Built Environment, \\ UCSI University, Kuala Lumpur, Malaysia \\ 3 Department of Architecture, Faculty of Engineering and Architecture, \\ Istanbul Gelisim University, Istanbul, Turkey
}

intanlianasamsudin.edu@gmail.com, zurinda@ucsiuniversity.edu,my, ida@ucsiuniversity.edu.my, yadodo@gelisim.edu.tr Tel: $+6017-8731277$

\begin{abstract}
The research aims to outline the design strategy for a mosque as a third place to promote an inclusive community friendly place. The research employs a qualitative case study methodology through observation and interview. The findings reveal that an inclusive mosque architecture can be enhanced based on the following design strategies: scale intimacy, ease of previewing, minimalist and adaptive building, space ambient, and impermanence landscaping character. Above all, the relationship between design, function, space and programming should be reestablished to infuse the mosque's inclusion for the benefit of all faiths, particularly the community.
\end{abstract}

Keywords: Multifaith Communal Area; Mosque Design and Contextualism.

eISSN: 2398-4287@ 2021. The Authors. Published for AMER ABRA cE-Bs by e-International Publishing House, Ltd., UK. This is an open access article under the CC BYNCND license (http://creativecommons.org/licenses/by-nc-nd/4.0/). Peer-review under responsibility of AMER (Association of Malaysian Environment-Behaviour Researchers), ABRA (Association of Behavioural Researchers on Asians/Africans/Arabians) and cE-Bs (Centre for Environment-Behaviour Studies), Faculty of Architecture, Planning \& Surveying, Universiti Teknologi MARA, Malaysia DOI: https://doi.org/10.21834/ebpj.v6i18.2972

\subsection{Introduction}

Our beloved Malaysia is a small developing nation, a melting pot of cultures due to our diverse population of 32 million citizens. In such a scenario, there is an ever-increasing need for multi-faith communities due to racial tensions in the past. The bond amongst Malaysians must be strengthened in the name of unity and fraternity. One approach to this is to strengthen the communal bond in third place, which refers to a unique communal space for social interaction, offering a setting for companionability, freedom, community assembly, and expression of feelings (Jeffres et al., 2009). The mosque is one of the third places commonly found in the neighbourhood or residential development area. However, the current mosque design offers limited engagement for public usage. The social inclusivity of mosque design is disappeared over time. There is insufficient effort has been made to convert open spaces in mosques into attractive and beneficial public spaces that promote intercultural engagement within the community (Mohamad Rasdi, 2010). The mosque should be an ideal space for the Muslim and non-Muslim communities to engage in social and communal activities (Najafi \& Shariff, 2011; Fridolfsson \& Elander, 2012; Nizarudin, 2016;). In regards to this idea, is it possible for mosques to be an arena in which the people can develop friendships and connections with others and offer a sense of belonging to a multi-faith community? Is it possible for mosques' design to foster contact and

eISSN: 2398-4287C 2021. The Authors. Published for AMER ABRA cE-Bs by e-International Publishing House, Ltd., UK. This is an open access article under the CC BYNCND license (http://creativecommons.org/licenses/by-nc-nd/4.0/). Peer-review under responsibility of AMER (Association of Malaysian Environment-Behaviour Researchers), ABRA (Association of Behavioural Researchers on Asians/Africans/Arabians) and cE-Bs (Centre for Environment-Behaviour Studies), Faculty of Architecture, Planning \& Surveying, Universiti Teknologi MARA, Malaysia.

DOI: https://doi.org/10.21834/ebpj.v6i18.2972 
bridge social capital? Multi-faith space is one of the possible concepts to encourage the welcoming and universal adaptation of reinterpreting the shared religious space. The multi-faith design is usually present at public buildings such as universities and airports (Johnson \& Laurence, 2012; Cadge, 2018). Although this concept emphasises a new sacred environment for worship, the architectural aspect of the multi-faith space should be examined to determine the in-between line to improve the architect and community interpretation of mosque architecture. Hence, the study aimed to outline the design strategy for a mosque as a third place to promote an inclusive community friendly place. Objectives of the research are (i) describing the architecture of mosques and multi-faith space concept, (ii) to appraise a mosque's design approach toward the multi-faith architectural response and (iii) to outline the design strategy of mosque place for communal and social inclusivity. The scope of this research is to focus on the mosque in the immediate vicinity and the surrounding community neighbourhood area.

\subsection{Literature Review}

The word "mosque" is derived from the Arabic word "sajada", which means "prostrate", where it refers to the place for sujud (Mohamad Rasdi, 1998). Since the great Islamic era, mosques have been seen as a hub for the Muslim community where communal activities and integration were transpired (Tamuri et al., 2012). Additionally, mosques are the focal centre for Muslims to perform religious, political, social and educational activities. Previous research has highlighted there are four elements of mosque architecture. This element includes main elements (prayer hall and minaret), complementary elements (courtyard, ablution, and female zone), additional elements (caretaker room, library) and detailing (niche, pulpit). These components are important in mosque architecture because they represent a symbolic identity (Asfour, 2016). However, geographical and climatic conditions may influence certain interpretations of mosque architecture and identity. One of the unique approaches for mosque design is community mosque, especially in regards to multi-faith communities. Spatial organisation, form, materiality, and local character are design strategies of community mosques (Jaafar et al., 2020). The communal mosque's form relates to the façade, ornamentation, detailing, structure, material, setting, and scale character (Baharudin \& Ismail, 2014). The mosque environment must be appealing, reachable, and accessible to everybody to generate a public space character (Najafi \& Mohd Shariff, 2013; Jaafar et al., 2020).

The multi-faith concept is one of the modern architectures that reflects a global aspect of a religious building to meet the public need of space. Multi-faith architecture is a modern version of old religious architecture with a simpler design and a theme that adheres to contemporary designs. According to (Velasco, 2014), the phenomenon of multi-faith space is global, as it complies with the need to propose places of worship or quiet reflection in specific settings, such as airports or transport stations, cemeteries and chapels of rest, hospitals, prisons, military quarters, homes for the elderly, centres of education and recreation, and even shopping malls and work centres. Generally, a multi-faith space is often interpreted as a single space design rather than a place design. However, recently, multi-faith spaces began to move away from being attached to these institutions and emerged as standalone projects. For example, in Berlin, a priest, a rabbi and an imam decided to erect a joint church of three monotheistic religions under the name "House of One". Some of the common fundamentals applied in designing a multi-faith space are the concern on space materiality and blurring the line of singular faith (Crompton, 2013). Moreover, it should be built, executed, and organised to be appropriate or acceptable to all users and hold a neutral character (Velasco, 2014).

Architecture illustration must create a particular vision of the religious ideal: a way of being in the world that believers aspire to and foster a sense of identity and belonging in the present (Davies \& Thate, 2017). The architecture of shared space needs to be considered to encourage the placement of multi-faith social areas within mosque setback. The connection between mosque architecture, communal mosques, and multi-faith spaces demonstrates the importance of materiality in space design. However, other aspects such as the context, scale, form, visual access, materiality, and landscape need a clear measure to support the concept of a friendly mosque for community social capital.

\subsection{Methodology}

The research used a qualitative case study method. This methodology helps to explore a phenomenon within some context through various data sources, and it undertakes the exploration through a variety of lenses to reveal multiple facets of the phenomenon (Baxter \& Jack, 2008). The Al-Mujahideen Mosque (AM) was chosen as a case study due to the rich context of the mosque adjacent to the Lutheran Church (LC) at Damansara Utama Selangor. Figure 1 indicates the context of the case study area.

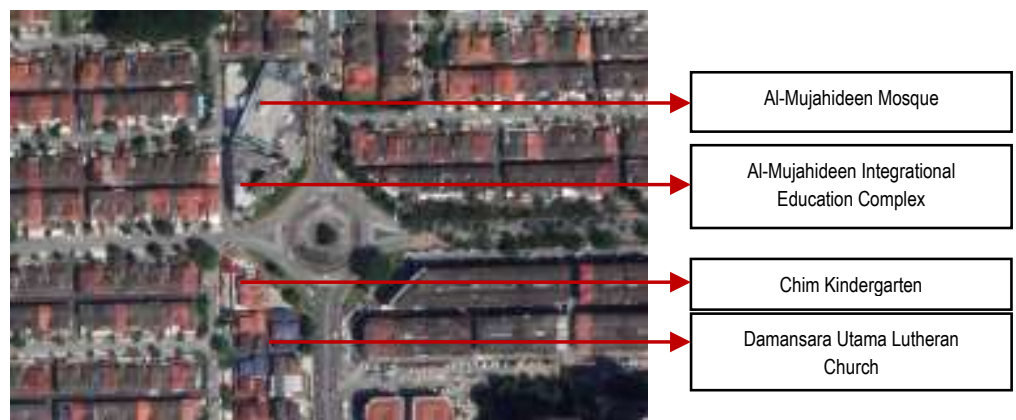

Figure 1: Al-Mujahideen contextualism 
The common case study research methods are interviews, structured surveys, observation, and document review (Mohd Tobi, 2019). The first method used in the research is observation to disclose the mosque's design quality in encouraging multi-faith communal features within the community. This observation activity is assessed using descriptive analysis. The six observation criteria are context, scale and massing, form and architecture style, visual access, materiality, and landscape. Secondly, a semi-structured interview was conducted with a representative from Al-Mujahideen mosque. The interview questions were divided into three sections: background information, perception of mosque imageability and multi-faith communal area. The content analysis method is used to analyse semi-structured interviews. The process involved in the content analysis is preparation, organisation and reporting (Elo \& Kyngäs, 2008).

\subsection{Findings}

Al-Mujahideen Mosque (AM) is a mosque in Damansara Utama, Selangor, Malaysia. It is located in the heart of the community core, close to businesses, hotels, residential neighbourhoods, and the DU park. Al-Mujahideen Integration Education Complex is also located within the same compound as the mosque area. The complex includes an Islamic Kindergarten where Muslim residents can enrol their children to immerse themselves in Islamic education. Additionally, the facility contains a Zakat premise. Historically, the mosque was first constructed as a surau by the locals but expended and converted into a mosque using private funds raised by locals. Previously, the mosque was taken over by the Selangor state religious affairs department (JAIS) for 9 years before returning to the local gariah (district/community) members. The mosque's southern section is home to the Damansara Utama Lutheran Church (LC). Both the mosque and church have a prominent presence in the neighbourhood and serve as third place for the community, particularly in religious gatherings. This research expands on the design criteria for AM in response to the multi-faith community plan. The domain, subdomains, design quality, and design strategy application of AM are listed in Table I.

Table I: The design strategy of Al-Mujahideen Mosque

\begin{tabular}{|c|c|c|c|}
\hline Domains & Sub-Domain & Design Quality & Design Application \\
\hline \multirow[t]{2}{*}{ Context } & $\begin{array}{l}\text { Contextualism } \\
\text { category }\end{array}$ & Residential zone & $\begin{array}{l}\text { - The AM is in the ring of the residential zone region. The environment lends itself well to the } \\
\text { idea of a mosque as a communal space. }\end{array}$ \\
\hline & & Fine-grain fabric & $\begin{array}{l}\text { - The fine grain development allows easy navigation of street patterns to the mosque/church } \\
\text { area. } \\
\text { - The AM orientation is "qiblat". The parallel orientation of AM to the roundabout offers a sense } \\
\text { of landmark for the mosque, located at the significant void area (roundabout) and building } \\
\text { orientation differs from the residential fabric orientation. }\end{array}$ \\
\hline
\end{tabular}

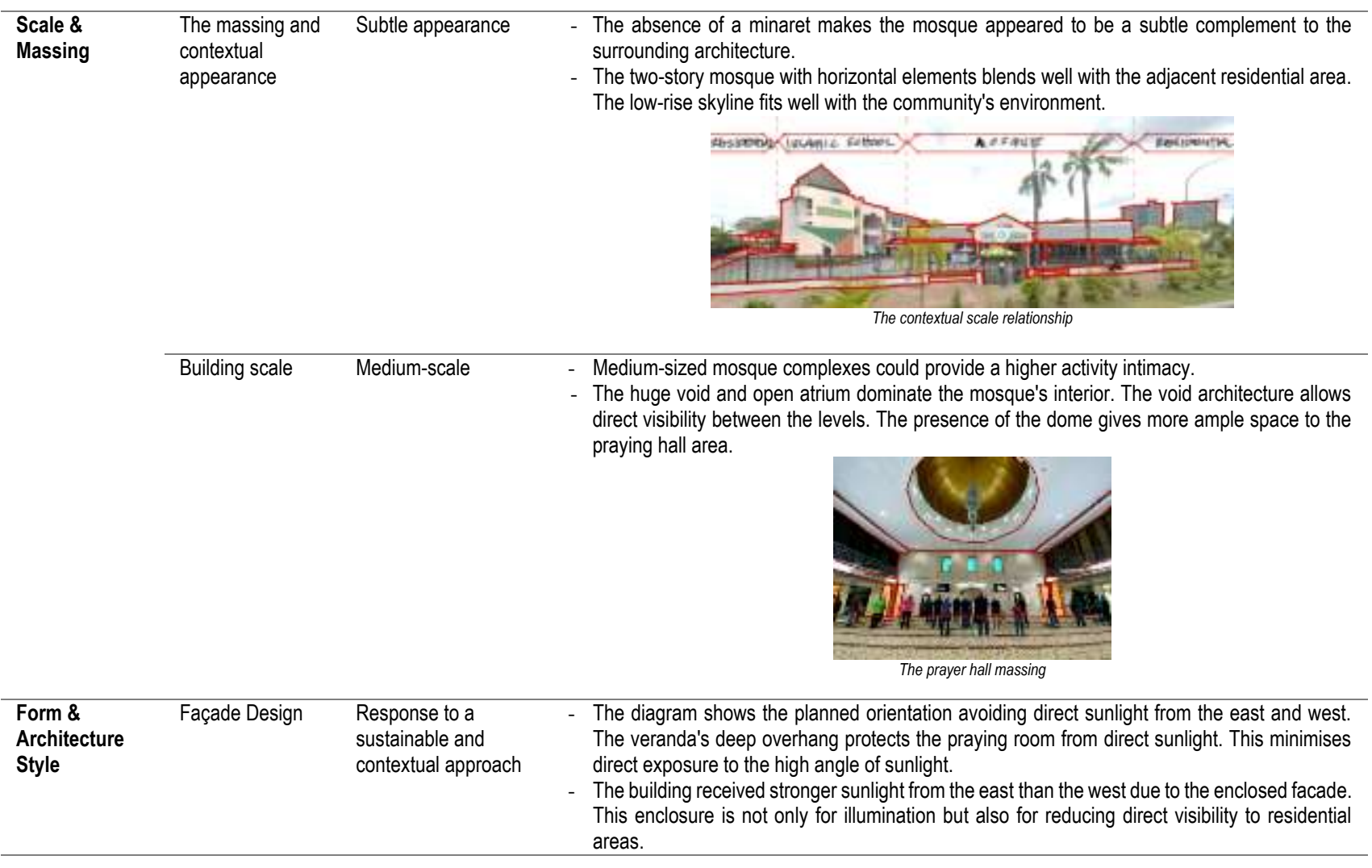




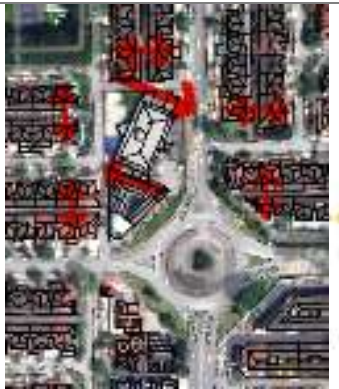

Mosque orientation

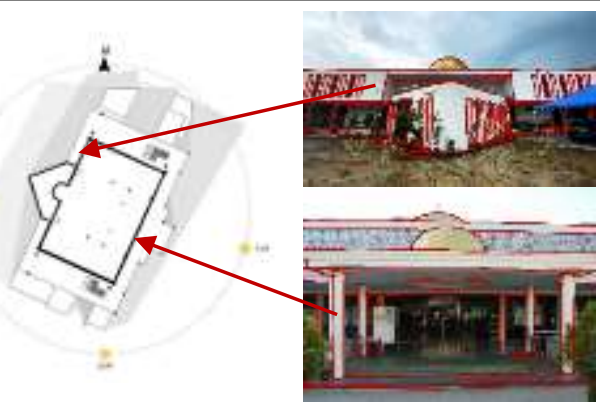

The sun path orientation

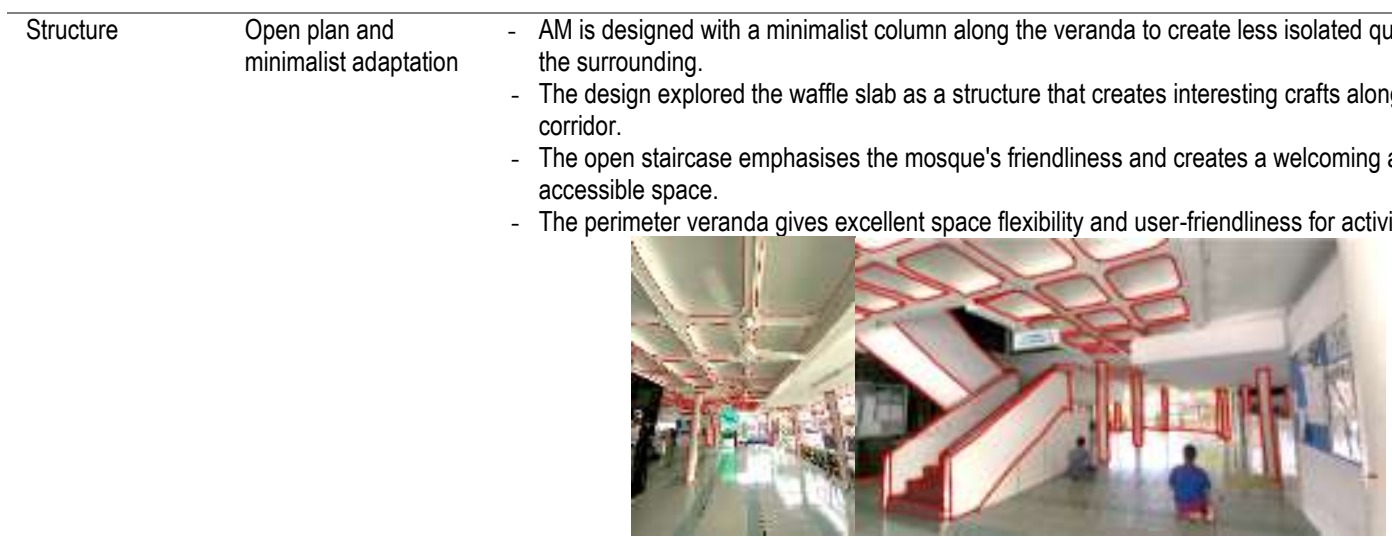

The structure: waffle slab and round column

Architecture style The symbolism of modern, islamic, and regional architectural approach
- The AM building's symmetrical plan layout, dome design, and geometrical facade are influenced by Islamic architecture, while the column and waffle slab represents modern design adaptability. Meanwhile, the roof and open veranda design represent the regional attitude.

- The AM uses many style adaptations to produce its identity on the building façade, rather than focusing on the strong symbolism of Islamic architectural style.

\begin{tabular}{lll}
\hline Visual Access & External Preview & $\begin{array}{l}\text { High visibility and } \\
\text { accessibility }\end{array}$
\end{tabular}

- The multiple entrances of the mosque also create a welcoming scene from all directions. Its large gates with intricate calligraphy carvings illustrate the artistic side of Islam, which intrigue and attracts its audiences inside the compound to feel the architectural phenomenology present within.

- The roundabout entrances provide a clear permeability and visibility as they access the AM as a pedestrian entrance.

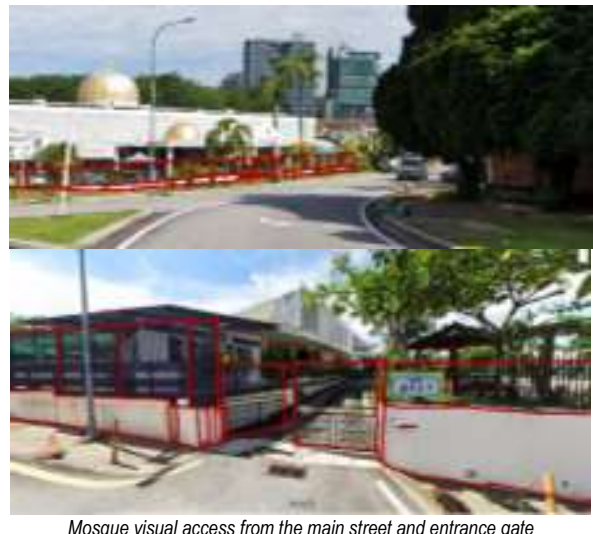

Mosque visual access from the main street and entrance gate Transparent perimeter
control
- The mosque's compound is surrounded by non-obstructive gates and walls, creating a transparent and open atmosphere. The mosque's surrounding fencing protects the compound from outside hazards while demonstrating that a contained environment is not always isolationist.

- The calligraphy entryway produces a clear landmark statement, but it may also impede the public from entering the site due to its strong symbolism. 


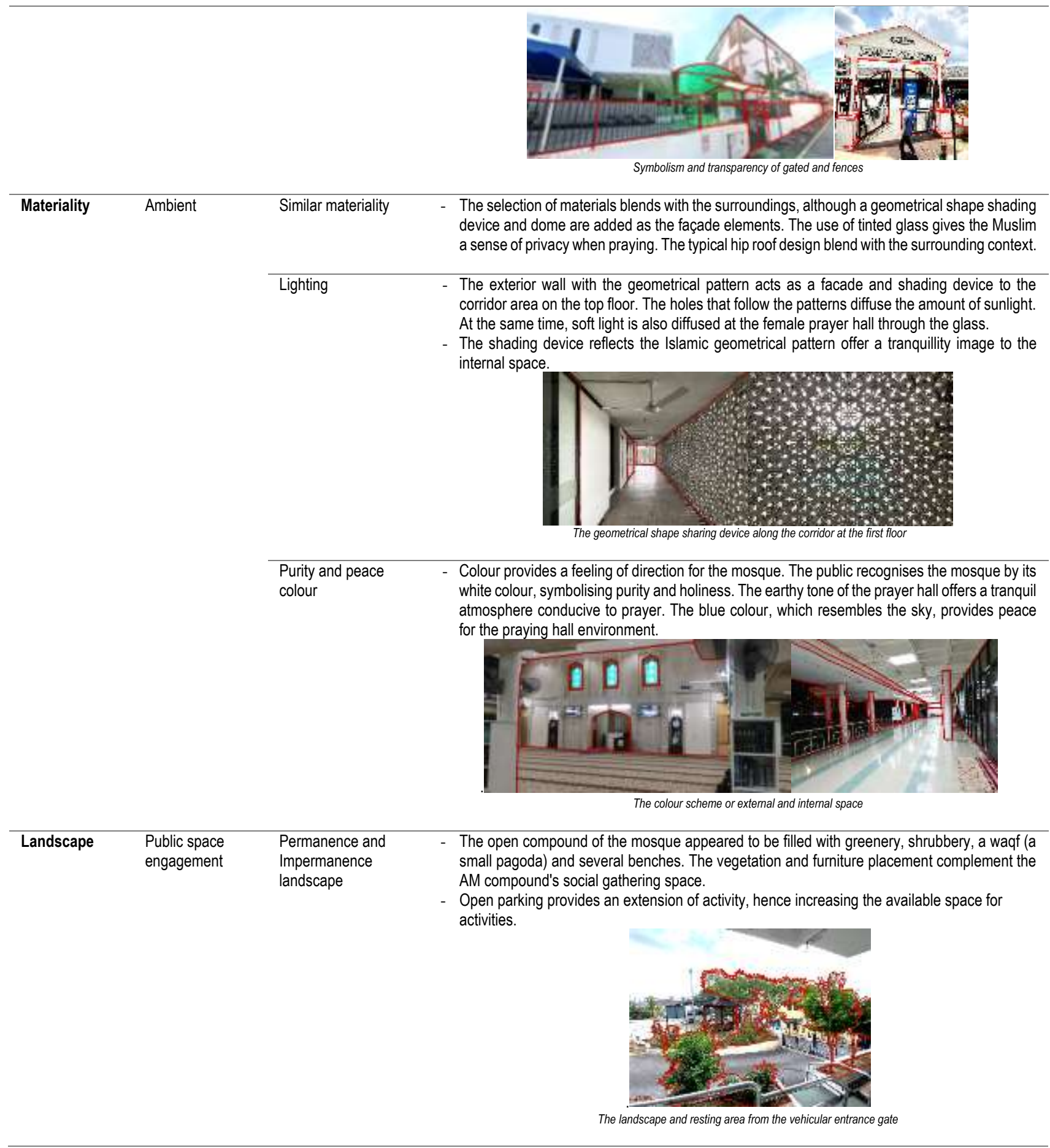

Apart from the observational data, three critical factors were discovered supporting the mosque as a multifaith-friendly place. Place and space function are critical to addressing the community's needs rather than the architectural impression need. The local need for space determines the addition and subtraction of AM design. The renovation of AM includes the renovation of the first floor, the construction of an adjacent school, and the addition of hall space while removing the minaret eliminates the existing features of typical mosque design. The removal of the minaret demonstrates that mosque architecture can be rethought to avoid adopting a minaret design feature as the current tower serves merely to accommodate a speaker for adhan purposes. However, for some individuals, the concept of having a minaret as one of the mosque's design characteristics is ingrained.

"Before this, the mosque doesn't have minaret due to the land being small, initially the land belongs fire as rescue department, then later the land has been gazetted as waqf. Later, one minaret was built, however, the location of the minaret is not suitable. The minaret later has been demolished due to safety reasons because it is located at parking space area, the presence of the minaret has disturbed the circulation cause the location is at the centre of parking circulation. The minaret needs a suitable position to avoid accident and injuries" 
A hybrid typology of mosque setting integrated with an educational complex brings additional value to the community-friendly character. Hall and library at the complex add a welcoming quality of AM. However, security should be considered as a school or educational site needs a certain boundary, especially during school hours. The advantage of these integrated facilities is that they allow for a multi-function activity for social, educational, or religious purposes.

"The hall is used for activity such as festive banquet."

"There is a certain time that the mosque area is used for the fire safety rehearsal and information day, the healthcare talk, the class for adults or for children such as recite activity. Non-muslim are also welcome, there is one Chinese who have joined us in the activity at this mosque area."

The third point is about space and programme relationships. Open layouts such as the veranda area offer continuous engagement space, suitable for either structured or unstructured programmes.

"Normally, the veranda or the corridor area are also used by people such as travellers and to those who cannot tolerate air conditioning, there usually prefer to pray at the open space. The corridor is also used as a temporary eatery space. During festive season such as Eid-ul-Fitr the indoor and outdoor are fully occupied same goes to the corridor area."

"For this mosque, the front space is open and has a glass. This is a good solution as the praying activity can be done in a bigger group. If there is an enclosure or room, this may cause the praying activity to depend solely on the mosque capacity."

Moreover, to encourage a less isolationist image, the program plays an important role in developing an attachment of place to the community. As per interviews, a structured programme is the most common situation for multi-faith religious gatherings at mosques. For example, the wedding and talk session. Cultural, sports, and humanitarian initiatives could benefit the neighbourhood and help develop a place identity. The form, function and meaningful programme are crucial in achieving a multi-faith social agenda. The meaning and attachment through the program can develop a collective bond to the existing community.

"There was an archery ceremony with the youth, but it was played outside of mosque compound, and there were non-Muslims also accompanying it." "In the certain event such as marriage ceremony, the events have a multiracial visitor."

"The food bank table in front of the mosque has invited those who in need to take the food resources regardless the religion."

\subsection{Discussion and Conclusion}

Mosque architecture is not a new topic in the multi-faith contextualism community. Through literature, community mosque design strategy should be further enhanced and not limited to the spatial organisation, form, materiality and visual access. The multi-faith space strategy offers insight into what is important to blur the strong symbolism of Islamic architecture for mosque design. Neutrality, materiality and universal adaptation can be the basic construct to design the public space for the multi-faith community. Additional mosque elements such as libraries and verandas should be considered a multi-faith strategy to enhance a friendly and welcoming image. The overtime adaptation has improved the AM design quality, especially for the Muslim community. However, there is a lack of multi-faith and intercultural engagement in the mosque. In terms of design, AM has successfully developed an integrated facility within strategic contextualism. The mosque is designed with (i) intimate scale quality, (ii) offer ease of preview, (iii) minimalist and adaptive architectural style, (iv) offer flexible space with a degree of the universal and neutral design approach, and (v) the place is designed with a permanence and impermanence landscape for social gathering activity. These strategies can be the base for the future design consideration of mosque design to further enhance the multi-faith friendly place. In addition to this, it is essential to further enhance the contextualism character between AM and LC. For instance, improving the softscape that connects these two religious centres is significantly needed. Moreover, as the research is only focused more on AM, there is an urgency for the mosque and church committee to discourse and share a common interest in utilising a sacred place as part of community gathering and development. Developing internal religious, ethnic and cultural bonds helps bridge the dissimilarity of faith through interreligious dialogue (Fridolfsson \& Elander, 2012). Future research could look into the design strategy of churches or temple places to enhance the multi-faith friendly character. In short, to establish a multifaith-friendly agenda, the process is not a single layer of development where form and function are crucial, but meaningful programmes are also needed to reestablish an inclusive mosque identity.

\section{Acknowledgements}

Thank you to CERVIE and UCSI University for funding (REIG-FETBE-2020/061). Thank you to School of Architecture and Build Environment for the architectural documentation of Al-Mujahideen Mosque and Ahmad Akif Aiman Khairuddin for research support.

\section{Paper Contribution to Related Field of Study}

This research explores the Mosque Architecture Community Environment.

\section{References}

Asfour, O. S. (2016). Bridging The Gap Between The Past And The Present: A Reconsideration Of Mosque Architectural Elements. Journal of Islamic Architecture, 4(2), 77. https://doi.org/10.18860/jia.v4i2.3559 
Behavioral Sciences, 153, 106-120. https://doi.org/10.1016/j.sbspro.2014.10.046

Baxter, P., \& Jack, S. (2008). Qualitative Case Study Methodology: Study Design and Implementation for Novice Researchers. The Qualitative Report, 13(4), 544-559. https://doi.org/10.46743/2160-3715/2008.1573

Cadge, W. (2018). The Evolution of American Airport Chapels: Local Negotiations in Religiously Pluralistic Contexts. Religion and American Culture: A Journal of Interpretation, 28(1), 135-165. https://doi.org/10.1525/rac.2018.28.1.135

Crompton, A. (2013). The architecture of multifaith spaces: God leaves the building. Journal of Architecture, 18(4), 474-496. https://doi.org/10.1080/13602365.2013.821149

Davies, D. J., \& Thate, M. J. (2017). Monstrosities: Religion, identity and belief. Religions, 8(6), 102. https://doi.org/10.3390/rel8060102

Elo, S., \& Kyngäs, H. (2008). The qualitative content analysis process. Journal of Advanced Nursing, 62(1), 107-115. https://doi.org/10.1111/j.1365-2648.2007.04569.x

Fridolfsson, C., \& Elander, I. (2012). Faith and place: Constructing Muslim identity in a secular Lutheran society. Cultural Geographies, 20(3), 319-337. https://doi.org/10.1177/1474474012464024

Jaafar, N., Harun, N. Z., \& Abdullah, A. (2020). ENLIVENING THE MOSQUE AS A PUBLIC SPACE FOR SOCIAL SUSTAINABILITY OF TRADITIONAL MALAY SETTLEMENTS. Pnanning Malaysia, 18(2), 145-157.

Jeffres, L. W., Bracken, C. C., Jian, G., \& Casey, M. F. (2009). The impact of third places on community quality of life. Applied Research in Quality of Life, 4(4), 333.

Johnson, K., \& Laurence, P. (2012). Multi-faith religious spaces on college and university campuses. Religion and Education, 39(1), 48-63. https://doi.org/10.1080/15507394.2012.648579

Mohamad Rasdi, M. T. (1998). The Mosque as a Community Development Centre: Programme and Architectural Design Guidelines for Contemporary Muslim Societies. Universiti Teknologi Malaysia.

Mohamad Rasdi, M. T. (2010). Rethinking Islamic Architecture. Strategic Information and Research Development Centre.

Mohd Tobi, S. U. (2019). Qualitative Research, Interview Analysis \& Nvivo 12 Exploration (1st Edition).

Najafi, M., \& Shariff, M. K. B. M. (2011). Factors influencing public attachment to mosques in Malaysia. Archnet-IJAR, 5(3), 7-24. https://doi.org/10.26687/archnetijar.v5i3.204

Najafi, M. (2013). Place Attachment to Contemporary Public-funded Mosques in Malaysia: A Study of People's Perception. LAP LAMBERT Academic Publishing.

Nizarudin, N. D. (2016). Spatial and Sociocultural Aspects of Urban Mosque Open Spaces in Kuala Lumpur, Malaysia: A mixed-method approach. Environment-Behaviour Proceedings Journal, 1(2), 43. https://doi.org/10.21834/e-bpj.v1i2.254

Tamuri, A. H., Ismail, M. F., \& Jasmi, K. A. (2012). A New Approach in Islamic Education: Mosque Based Teaching and Learning. JIAE: Journal of Islamic and Arabic Education, 4(1), 1-12. http://www.ukm.edu.my/jiae/pdf/37.pdf

Velasco, F. D. (2014). Multi-belief/multi-faith spaces: Theoretical proposals for a neutral and operational design. In Multireligious Society: Dealing with Religious Diversity in Theory and Practice (Issue No. 26). https://doi.org/10.4324/9781315407586 